\title{
Model For Improving Performance Of Employees Based On Organizational Commitment, Role Conflict And Emotional Intelligence In Education In Bandung Islamic University
}

\author{
Mochamad Vrans Romi' ${ }^{1}$, Eeng Ahman², Andri Irawan³, Asep Kurniawan ${ }^{4}$, Hernandi \\ Sujono 5 \\ \{vransromi@gmail.com¹, eengahman@yahoo.co.id ${ }^{2}$, andri.irawan@lecture.unjani.ac.id ${ }^{3}$, \\ asepkurniawan2010@gmail.com ${ }^{4}$, hernandi_s@yahoo.co.id ${ }^{5}$ \}

\footnotetext{
${ }^{1,2}$ Universitas Pendidikan Indonesia Jl. Dr. Setiabudi No.229, Isola, Kec. Sukasari, Bandung, Jawa Barat, Indonesia

${ }^{3,4,5}$ Universitas Jenderal Achmad Yani, Jl. Terusan Jenderal Sudirman Cimahi, Jawa Barat, Indonesia
}

\begin{abstract}
The main objective in the research has been to produce a performance enhancement model through the organizational commitment of the role conflict and the emotional intelligence of educational personnel in the Islamic University of Bandung, where the subject used in This research is an educational force that is scattered in several faculties and other parts. The number of samples in this study was 78 educational personnel chosen using the Purposive sampling method, as well as using the moderate Regression Analysis (MRA) analysis tool. The results of the analysis obtained in this study showed that the variables of the organizational commitments are positive and significant to the employee's performance, variable role conflicts negatively and significantly affect the power performance variables Educational. Emotional intelligence moderate the organization's commitment to performance is demonstrated with the significance value 0.029 which is smaller than the probability 0.05 and the coefficient value of the determination of 0.412 a large lebi of the value of coefficient of influence determination Organizational commitment to employee performance. Emotional intelligence moderate role conflicts towards employee performance demonstrated by the 0.007 interaction test value and coefficient of determination value of 0.342 greater than the value of coefficient of influence of variable role conflict for variables Employee performance, this implies that the variable of emotional intelligence weakens the effect of variable conflict of role on the performance variables of educational personnel at the Islamic University of Bandung.
\end{abstract}

Keywords: Organizational Commitment, Role Conflict And Emotional Intelligence, Performance

\section{Introduction}

Role conflict is related to stress symptoms experienced by members of the organization, where this can cause discomfort when the employee is working and potentially affect the decrease in motivation which will later have an impact on employee performance. Stress caused by role conflict will lead to job dissatisfaction and will also affect organizational commitment and decrease performance. [1]. The organizational commitment is a level in which an employee is more favorited to a particular company and its objectives and also 
intends to maintain the organization's membership [2]. One educational institution that is also always trying to improve its performance is Bandung Islamic University. The role of the teaching staff in this case lecturers and education staff becomes one of the important aspects in terms of improving the quality of education where services to student needs from student satisfaction index data on various aspects of assessment still tend to be low.

Based on previous research shows that organizational commitments affect employee performance [3], [4], [5], [6]. the results of this study prove that organizational commitment has a positive and significant effect on performance. Employee commitment is not the only problem in Bandung Islamic University, another problem is role conflict. Role conflict is one of the drivers of increasing and decreasing employee performance. Role conflict is a conflict that arises because the organization's bureaucratic control mechanism is not in accordance with norms, rules, ethics and professional independence [2]. Based on several previous studies that support research on role conflict affect employee performance such as [7], [8]. An employee who works in a company will work in accordance with the rights and responsibilities of the, so that when the employee has a sense of commitment to the company where he works, then the employee will work as much as possible in accordance with the duties and authority in the company. Research on organizational commitment, role conflict and employee performance, there are previous research results that show a unidirectional relationship or negative influence between variables, there are also results of previous studies that show a direct relationship or positive influence.

\section{Literatur Review}

\subsection{Organizational Commitment}

Employee commitment is a form in which employees have involvement, accept existing environmental conditions, and strive to excel and serve. [9] expressing Commitment is a force that is relatively identifying each individual and involvement in interacting with a particular organization. [10] expressing commitment is the power that binds an individual to an action that is relevant to one or several goals. [11] Commitment is an attitude that will reward employee loyalty to an organization and also reflects an ongoing process in which the organizations in the Organization demonstrate their concern for organizational progress, Success, and prosperity.

\subsection{Role Conflict}

The definition of conflict as a conflict that occurs between what is expected by someone against himself, others, organizations with the reality of what he hoped [12]. in line with that [7] defining role conflict is related to the dimensions of conformity or suitability to the requirements of a role [13]. Conflict is something that can not be avoided in the company but can be resolved and appeased at a minimum and does not interfere with the smooth running of the company [14].

\subsection{Emotional Intelligence}

Emotional intelligence can be interpreted as an ability to perceive, understand, and effectively apply the power and sensitivity of emotions as source, information, energy, 
connection, and human influence. [15]. emotional intelligence is conceptually different from personality [16] said that what is meant by emotional intelligence in it includes the ability to control oneself, stimulate, persevere, and be able to motivate yourself [17].

\subsection{Employee performance}

According to Wilson (2012) in [18] expressing Employee performance is the result achieved in carrying out a job based on the requirements that have been met in conducting the work. Performance can also be interpreted as a result of work measured in quantity and quality obtained by an employee in carrying out its obligations and duties in accordance with the responsibilities that the company has given to him [12].

\subsection{Effect of organizational commitment on employee performance}

Individuals who have low organizational commitment will tend to do ways that can interfere with organizational performance such as high turnover, inaction at work, complaints and even strikes. Individuals who have high organizational commitment tend to do ways that can increase job satisfaction that have an impact on improving employee performance. This research is supported by several research journals regarding the effect of organizational commitment on employee performance. Like the research conducted [19], [20], [21] [22] H1: Organizational Commitment has a positive and significant influence on Employee Performance.

\subsection{The Influence of Role Conflict on Employee Performance.}

Role conflict is a condition where the employee gets more than one order which if only focused on doing one order then the other orders will be ignored, this kind of situation will bring up anxiety, anxiety, and discomfort of the employee in the work environment which will reduce performance and impact on behaviors other individuals interacting within a company or organization. This research is supported by several research journals regarding the effect of role conflict on employee performance. Like the research conducted [23] [24], H2: Role conflict has a negative and significant impact on Employee Performance.

\subsection{Emotional Intelligence as a Moderation Variable between Organizational Commitment and Employee Performance.}

This research is supported by research on emotional intelligence as a moderating variable between organizational commitment and employee performance [3] H3: Emotional intelligence moderates the influence of Organizational Commitment and Employee Performance.

\subsection{Emotional Intelligence as a Variable of Moderation between Role Conflict and Employee Performance}

Emotional Intelligence as a Variable of Moderation between Role Conflict and Employee Performance Once an employee successfully escapes conflict without harming himself and others, the employee will return to completing his work easily. [17]. After employees have managed to get out of conflict properly without harming themselves and others, then the employee will return to work easily [17]. H4: Emotional intelligence moderates the influence of employee role conflict and performance 


\section{Methodology}

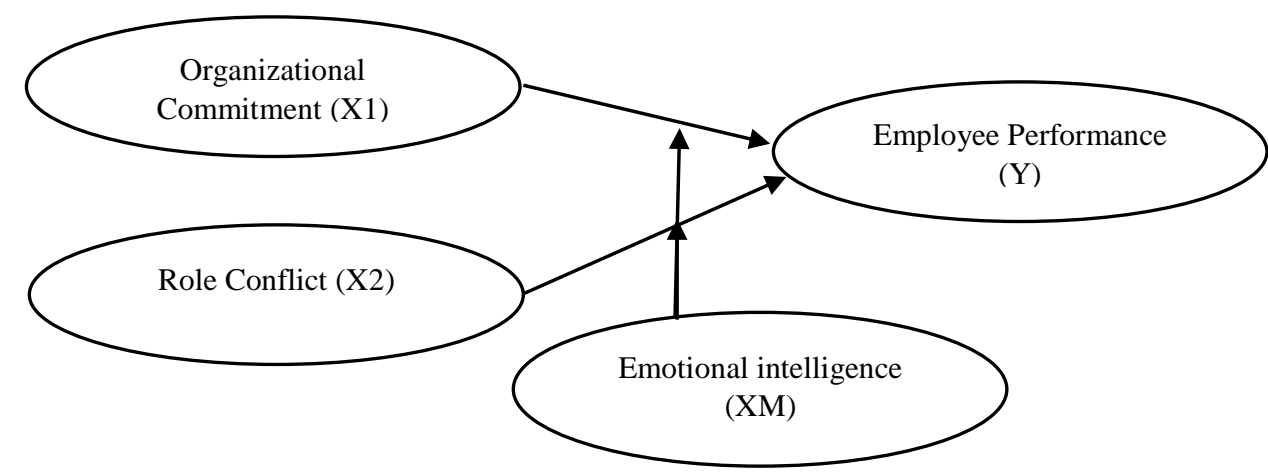

Fig. 1. Research Model

\subsection{Research Object}

The object of this research is Bandung Islamic University and the subject used is educational staff from various faculties and rectorates at Bandung Islamic University.

\subsection{Type Of Data Research}

The type of data used is primary data in the form of responses from respondents who were the subject of research on the questionnaire with variables of organizational commitment, role conflict, emotional intelligence and employee performance using a Likert scale.

\subsection{Population}

The population in this study were all educational staff at the Islamic University of Bandung, while the sample taken was 78 Educational Staff.

\subsection{Research Method}

Instrument testing is done by testing the validity and reliability, descriptive statistical tests, hypothesis testing (normality, multicollinearity, heteroscedasticity, linear regression, interaction test or Moderate Regression Analysis (MRA), Determination Coefficient Test.

\section{Result And Discussion}

1. Descriptive statistical results of this study The organizational commitment variable shows an average number of 3.83 with a minimum score of 1 and a maximum at number 5, this shows that the organizational commitment of educational staff in Bandung Islamic University falls into the high category.

2. Descriptive statistical results of this study The role conflict variable shows an average number of 2.51, this shows that the role conflict of the educational staff at the Islamic University of Bandung falls into the low category 
3. Descriptive statistical results of this study The variable of emotional intelligence shows an average number of 3.77 , this shows that the role conflict of the educational staff at Bandung Islamic University is in the high category.

4. Descriptive statistical results of this study Variables Employee performance variables showed an average number of 3.88, this shows that the teaching staff at the Islamic University of Bandung entered into the high category

5. Hypothesis testing

a. Variable commitments the organization has a positive and significant impact on employee performance variables where linear regression test hypothesis 1 Test Results influence variable organizational commitments to employee performance show significance value of 0.000 which means that the significance value is smaller than 0.05 with a positive regression coefficient seen from the standardized coefficient value of 0.575 . This means the organizational commitment variables have a significant positive influence on employee performance variables or $\mathrm{H} 1$ accepted. Coefficient of determination of 0.311 or $31.1 \%$. This means that organizational commitment has an influence on employee performance by $31.1 \%$ and the remaining $68.9 \%$ is influenced by other variables not tested in this study. This shows that the existence of organizational commitment in the teaching staff at the Bandung Islamic University is an important thing for every employee working in the place to have, so that the objectives of the agency can be achieved in line with previous research conducted by [21], [22], [20] [9].

b. A role conflict negatively and significantly affects the employee's performance variable where the test result influences the role of the employee's performance, indicating significance value value of 0.034 , which means that the significance value is less than 0.05 with a negative regression coefficient seen from the standardized coefficient of 0.335 . This means that role conflict has a significant negative effect on employee performance or $\mathrm{H} 2$ is accepted. the coefficient of determination is 0.100 or $10 \%$. This means that role conflict has an influence on employee performance by $10 \%$ and the remaining $90 \%$ is influenced by other variables not tested in this study. This means that if an employee's perceived role conflict increases then the employee's performance will decrease, in line with previous research as conducted by [24], [23].

c. Emotional intelligence moderate the influence of variable organizational commitments and employee performance variables where the influence of interaction of $\mathrm{X} 1 * \mathrm{Z}$ to employee performance obtained a significance value of 0.029 smaller than 0.05 then hypothesized that Emotional intelligence moderate the influence of organizational commitment variables against proven employee performance variables or $\mathrm{H} 3$ acceptable. Coefficient of determination value of 0.412 which means emotional intelligence reinforces the influence of the organization's commitment to employee performance because previously in the first regression of coefficient of determination of the Organization's commitment to organizational performance Charge of was 0.311 . If emotional intelligence weakens the positive influence of organizational commitment on performance, employees will feel unhappy because they work in their workplace and are not so concerned with the fate of their organization and will only make an effort to complete work at a normal level, this is in line with previous research [3]

d. Emotional Intelligence moderates the influence of Role Conflict and Employee Performance where the effect of $\mathrm{X} 1 * \mathrm{Z}$ interaction on employee performance gets a significance value of 0.006 less than 0.05 , the hypothesis stating that emotional intelligence moderates the effect of role conflict on proven employee performance or 
$\mathrm{H} 4$ is accepted. the coefficient of determination is 0.342 which means emotional intelligence weakens the influence of role conflict on employee performance because previously in the first regression the coefficient of determination of organizational commitment to organizational performance was 0.100 . emotional intelligence moderates the influence of role conflict on employee performance in line with research conducted by [23], [3].

\section{Conclusion}

From the results of analysis obtained in this study can be taken several conclusions as follows:

1. Variable organizational commitments positively and significantly affect employee performance variables.

2. Variable conflict roles negatively and significantly affect employee performance variables.

3. Variable emotional intelligence moderate the influence of variable organizational commitment to employee performance.

4. Emotional Intelligence variables moderate the influence of variable role conflict to performance

\section{References}

[1] S. Harningsih, Pengaruh Kompetensi Karyawan Dan Konflik Peran, 2012.

[2] S. P. Robbins, Organization behavior tenth edition ( Perilaku Organisasi , edisi sepuluh ) Alih bahasa Drs.Benyamin Molan, Jakarta: Salemba Empat, 2008.

[3] S. A. A. Y. \&. R. Ismail, "Pengaruh Role Stessor, Self-Efficacy,Sensitivitas Etika Profesi dan Komitmen Organisasi terhadap Kinerja Auditor dengan Emotional Quotient sebagai Variabel Moderating," JOM Fekon, vol. Vol.4 No.1., 2017.

[4] Saryanto, \& Amboningtyas, D, "Pengaruh Rotasi Kerja, Stres, Kepuasan Kerja Dan Komitmen Organisasi Terhadap Kinerja Karyawan (Studi Kasus Pada Ace Hardware Semarang)," 2017.

[5] Novelia, M., Swasto, B., \& Ruhana, I., "Pengaruh Komitmen Dan Organizational Citizenship Behavior (Ocb) Terhadap Kinerja (Studi Pada Tenaga Keperawatan Rumah Sakit Umum Daerah Dr. Soegiri Lamongan)," Jurnal Administrasi Bisnis (JAB), vol. Vol. 38 No.2, 2016.

[6] W. Handayani, "Dampak Komitmen Organisasi, Self Efficacy Terhadap Konflik Peran Dan Kinerja Karyawati PT. HM Sampoerna Tbk. di Surabaya," Jurnal Riset Ekonomi dan Bisnis, vol. Vol.8 No. 2, 2008.

[7] I. W. Yasa, "Pengaruh Konflik Peran Dan Ambiguitas Peran Terhadap Kinerja Pegawai Melalui Mediasi Stres Kerja Pada Dinas Kesehatan Kota Denpasar Bali," Jurnal Ekonomi \& Bisnis, Vols. Vol. 4 , No 1, 2017.

[8] F. Saranani, "Role conflict stress effect on the performance of the employees working in public work department," The international journal of, pp. 1-10, 2015.

[9] Edison, E., Anwar, Y., \& Komariyah, I., Manajemen Sumber Daya, Bandung: Alfabeta, 
2016.

[10] Meyer, J. P., Stanley, D. J., Herscovitch, L., \& Topolnytsky, L., "Affective, continuance and normative commitment to the organization: A metaanalysis of antecedents, correlates, and consequences.," Journal of Vocational Behavior, vol. 2, pp. 61, 20-52, 2002 .

[11] F. Luthans, Organizational Behavior, Seventh ed., New York: McGraw-Hill, 2005.

[12] A. P. Mangkunegara, Manajemen Sumber Daya Manusia Perusahaan., Bandung: PT Remaja Rosdakarya, 2013.

[13] J. R. Rizzo, "Role Conflict and Ambiguity in Complex Organizations," Administrative science quarterly, vol. I, pp. 150-163, 1970.

[14] V. Rivai, Manajemen Sumber Daya Manusia untuk Perusahaan., Jakarta: PT. Raja Grafindo Persada, 2004.

[15] R. K. Cooper, EXECUTIVE EQ Kecerdasan Emosional dalam Kepemimpinan dan Organisasi, Jakarta: PT Gramedia Pustaka Utama, 1998.

[16] C. L. Wong, "The construct and criterion validity of emotional intelligence and its potential utility for management studies," Journal of applied Psychology, 2004.

[17] D. Goleman, Kecerdasan Emosi untuk Mencapai Puncak Prestasi, Jakarta: PT Gramedia Pustaka Utama, 2003.

[18] R. Lufitasari, Pengaruh Motivasi Kerja, Disiplin Kerja Dan Kompensasi Terhadap Kinerja Karyawan Pada Dinas Pendapatan, Pengelolaan Keuangan Dan Aset Di Yogyakarta, Doctoral Dissertation, Fakultas Ekonomi.

[19] Fu, W., \& Deshpande, S. P., "The Impact of Caring Climate, Job Satisfaction, and Organizational Commitment on Job Performance of Employees in a China's Insurance Company," Journal of Business Ethics, vol. 124 (2), pp. 339-349, 2014.

[20] Tsui, P.-L., Lin, Y.-S., \& Yu, T.-H, "The Influence Of Psychological Contract And Organizational Commitment On Hospitality Employee Performance," Social Behavior and Personality: an international journal, 2013.

[21] M. Atmojo, "The Influence of Transformational Leadership on Job Satisfaction, Organizational Commitment, and Employee Performance. „" nternational Research Journal of Business Studies, vol. I vol. 5 no. 02, pp. 113 - 128, 2012.

[22] Wahyuni, D. U., Christiananta, B., \& Eliyana, A., "Influence of Organizational Commitment, Transactional Leadership, and Servant Leadership to the Work Motivation, Work Satisfaction and Work Performance of Teachers at Private Senior High Schools in Surabaya.," Educational Research International, vol. Vol. 3(2)., 2014.

[23] Afifah, U., Sari, R. N., Anugerah, R., \& Sanusi, Z. M. , "The Effect of Role Conflict, Self-efficacy, Professional Ethical Sensitivity on Auditor Performance with Emotional Quotient as Moderating Variable. ," Procedia Economics and Finance , vol. 31, p. 206 212, 2015.

[24] K. Celik, "The Effect of Role Ambiguity and Role Conflict on Performance of Vice Principals: The Mediating Role of Burnout," Egitim Arastirmalari-Eurasian Journal of Educational Research, vol. 51, pp. 195-214, 2013. 
